\title{
Tomorrow's Schools after 20 years: can a system of self-managing schools live up to its initial aims?
}

\section{Cathy Wylie}

\section{Abstract}

In 1989 the Tomorrow's Schools reforms brought in self-managing schools as the unit for educational administration. The government's stated aims included a mix of outcomes and processes, which were to: improve educational opportunities, meet Māori needs more effectively, give local knowledge real responsibility, and encourage flexibility and responsiveness. The system was to be more efficient, and provide greater accountability.

After 20 years, progress towards these aims is, at best, mixed. This article provides a broad overview of the frameworks for school self-management over this period, identifying two main phases from 1989 to 2009. The first led schools to develop inward-looking identities. The second introduced a greater emphasis on capability development. The ongoing legacy of the initial phase is discussed, since reform phases do not so much replace one another as build on what has already been established. It also discusses the shortcomings of each of these phases in relation to the aims of Tomorrow's Schools, and the kind of framing school self-management might need if it is to realise the aims of improved educational opportunities, particularly for Māori, given that this was an initial driver for the reforms.

\section{Introduction}

...to have any influence at all on the future you have got to know, first, where you've been, and next, the direction you want to go. (Beeby, 1983, p. 17)

1 The year 2009 was the $20^{\text {th }}$ anniversary of Tomorrow's Schools, the reform of educational administration that made some 2009, these changes were taken for granted by the many teachers and almost two generations of students who have known no other way to provide public education in New Zealand than through self-managing 
schools. However, the New Zealand changes are still thought of as radical by many overseas visitors. While in recent years other countries have seen growth in charter schools (and the like) operating more autonomously than their peers within the local public system, no other Western country bases its entire public system on stand-alone schools, each with their own parent-led board of trustees responsible for the school's direction and staff employment, and operating without being part of a school district, or local authority. ${ }^{1}$ Yet there is no evidence that giving schools control of their budgets and employment decisions per se has led to system-wide gains in student performance or learning, or new approaches to learning, or greater equality of educational opportunity (Wylie, 2000a). For example, improvements in the proportion of Māori students leaving school with a qualification only began in 2003, with a system-level change that saw the introduction of the new secondary qualification, the National Certificate of Educational Achievement (NCEA) (Robinson, Hohepa \& Lloyd, 2009, p. 59). The new system did enable the growth of Kura Kaupapa Māori, providing a Māori curriculum in te reo Māori, and now showing higher student performance in NCEA than for Māori attending English-medium schools (Minister of Education, 2010). Nonetheless, the development of Kura Kaupapa Māori has been hampered by ongoing difficulties in teacher supply, something largely outside the control of individual self-managing kura (Waitangi Tribunal, 2010).

How school self-management is framed has implications for its efficacy. ${ }^{2}$ Framing includes the way each school is situated vis-à-vis other schools and government agencies, the responsibilities they are given, the ways they are accountable, and the ways they are supported. I am interested particularly in how this framing influences the way schools operate and gain knowledge that they can bring to bear in their provision of educational opportunities. The New Zealand experience illustrates the shortcomings of: taking school self-management too literally; not realising that local capability needs deliberate development from the start through such strategies as situating schools within a nexus of relationships with neighbouring schools, and in relationships of support and challenge with government agencies; and not paying heed to the need for system learning which ongoing working relationships between different actors in the system make possible. This article revisits the intentions of the Tomorrow's Schools 
policy, and then outlines two phases evident in the New Zealand experience of self-managing schools, and the ongoing legacy of the first phase.

\title{
Tomorrow's schools: Aims and initial framing
}

David Lange was the Minister of Education and Prime Minister responsible for the introduction of Tomorrow's Schools (Minister of Education, 1988). In his foreword to the initial policy document that came after the Picot Taskforce report, and submissions on its recommendations, he stated:

\begin{abstract}
When the report of the Picot taskforce, Administering for Excellence, was released on 10 May, I acknowledged the broad merits of the model it proposed. It seemed to me to be a good mixture of responsiveness, flexibility, and accountability. It placed decision making as close as possible to the point of implementation..... The Government is certain that the reform it proposes will result in more immediate delivery of resources to schools, more parental and community involvement, and greater teacher responsibility. It will lead to improved learning opportunities for the children of this country. The reformed administration will be sufficiently flexible and responsive to meet the particular needs of Māori education. (Minister of Education, 1988, p. iii-iv)
\end{abstract}

These aims are broad, and they picked up a number of issues and themes that had come to the fore in the previous decade as the education system was criticised for not in fact providing equality of educational opportunity. A review of the curriculum supported more local framing, with greater parent and community involvement (Openshaw, 2009; Wylie 1988).

However, aims are nothing without processes, relationships, materials, and structures to bring them to life, and, as it turned out, these were the thinnest elements of Tomorrow's Schools. There are two main reasons for this: the overall economic and social reform context within which school self-management was introduced; and, linked to that, the lack of understanding of the importance of systemwide relationships and linkages for developing educational capability and capacity.

\section{The overall reform context}

The intentions of Tomorrow's Schools, and its original framing, showed tensions between equity and market emphases (Lauder, Wylie \& Parker-Taunoa, 1990), and around the accountability of schools: to both their local community, and central government (Codd, 1990; 
Ramsay, 1993; Wylie, 1995a). The general policy framework within which schools operated from 1990 owed much to the New Public Management reframing of public services, underpinned by a separation of functions, contractual relationships, and accountability arrangements that relied on contracts and reporting on outputs. This model was drawn from institutional economics, and made "positivist, mechanistic and linear-rational assumptions of bureaucratic behaviour" (Gregory, 2003, p. 43). Indeed, the New Zealand public service reforms enacted on this theoretical basis were put together in such a way that they also attracted international fascination, without emulation of the totality (Schick, 2001). Just as education today struggles to overcome the fragmentation that came with the reforms, and to find ways to tackle shared issues collectively (Eppel, 2009), so have the calls increased from within and outside the public service for more "joined-up" thinking and "cross-agency" purpose and work to tackle long-existing and exacerbating complex social, environmental, and economic issues (Norman \& Gregory, 2003; State Services Commission, 1999).

The sense of separation which prevailed in the first phase of school self-management, through the 1990s, is well illustrated by the diagrams showing the new system in the Tomorrow's Schools document (Minister of Education, 1988, pp. 16-17). For a start, note that there are two diagrams: accountability and support do not appear together.

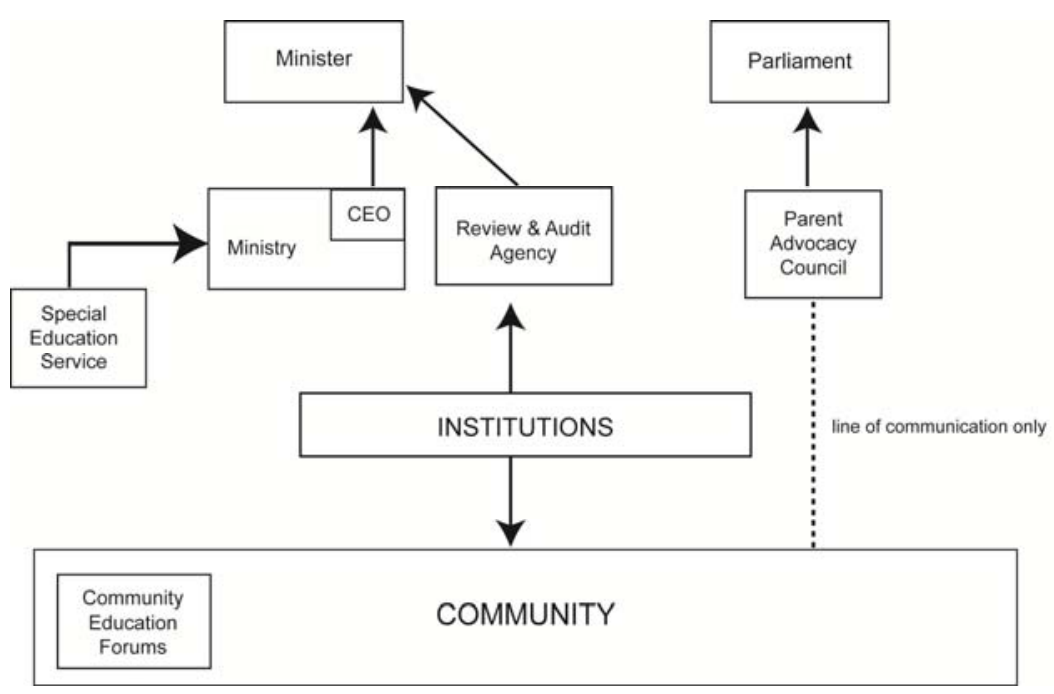

Figure 1: Lines of Accountability 


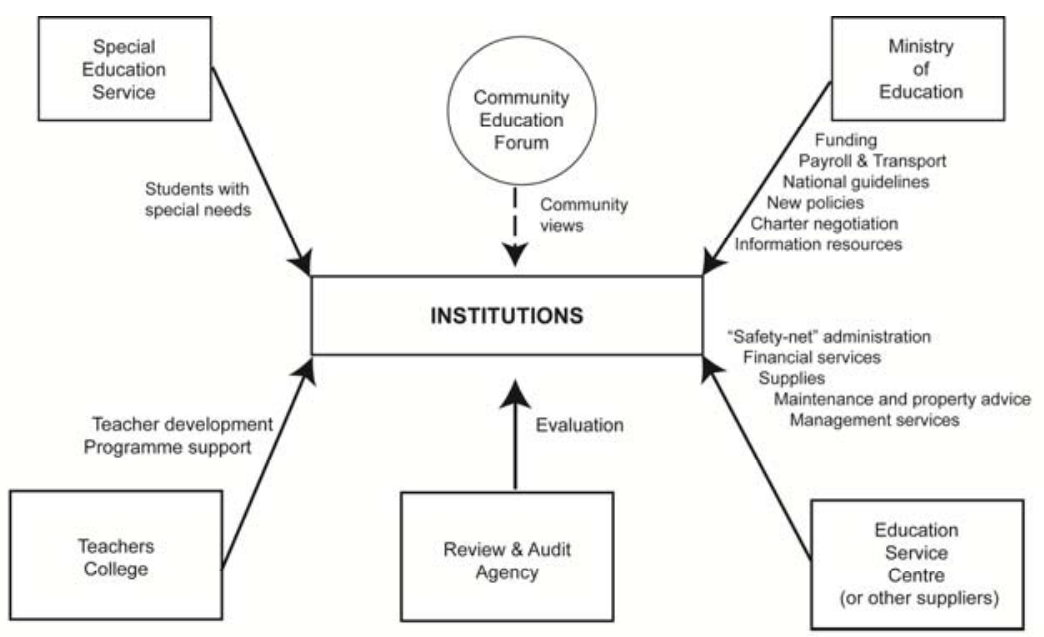

Figure 2: Meeting the needs of institutions

The planned links between organisations were limited to accountability, providing a service, or providing a framework. The only line of communication exists between the (nebulous) community, and the Parent Advocacy Council. Absences of structural communication links during the first phase of implementation caused difficulties for system learning. For example, there were no links of communication between the Review and Audit agency (the Education Review Office (ERO)'s original name) and the Ministry of Education. This was probably because the Review and Audit agency roles originally included comment on the "ministry's provision of policy advice and overseeing of policy implementation (as it affects the performance of institutions)" (Minister of Education, 1988, p. 21). But the lack of ongoing communication between the two agencies was to be a marked source of tension by the mid-1990s. Nor were there communication links between the Ministry of Education and the organisations providing support to individual institutions: the Special Education Service was to be accountable to the Ministry of Education, but delivered to schools. There were no two-way links between schools and the Ministry of Education.

Schools were originally accountable to the Review and Audit Agency - but not to the Ministry of Education. The Review and Audit Agency was originally intended to have a much closer relationship with schools, and a relationship that combined support and pressure, as recommended so often in recent years as a way to improve educational opportunities and performance (e.g., Elmore, 2004; Wylie, 2009). Here was the potential for some real learning at local level, if 
not beyond. It provided scope for the development of expertise and relationships that could see and serve beyond the individual school, that would provide the balance needed to temper the self-focus that came with schools as separate self-managing units, and processes for the collective learning of new approaches that would be needed for the kind of improvement in educational opportunity and achievement envisaged by the intent of the reforms.

As originally set out, the Review and Audit Agency would use multi-disciplinary teams for its two-yearly reviews, including members who had expertise in curriculum, administration, equal employment opportunities, and equal educational opportunity matters, as well as a community representative, and a current principal. These teams would identify strengths and weaknesses, with recommendations for improvement, and visit the school a second time a term later to see what progress was being made, with a final report at that time. Schools, whose final reports included "serious deficiencies in the management of the institution or in the achievements of its students" (Minister of Education, 1988, p. 21), would be reviewed a third time six months later, and if significant improvement had not occurred, the board of trustees would then be able to be dismissed.

This developmental and localised approach, which contained within it some real powers to provide the checks and balances that school self-management needs, was halted before it could get underway. A further government review undertaken in early 1990 (Lough, 1990) sought to reduce educational spending and ensure that the educational reforms fitted with the wider public sector changes. ${ }^{3}$ Dale and Jesson (1993) described the Lough report as a re-litigation of some of the original New Public Management policy approach which had been knocked back when the Tomorrow's Schools outline was translated into implementation detail through a set of working groups that included educationalists, and considerations of equity.

Other checks and balances - structures and processes to deepen shared knowledge that would improve education and tackle systemic issues - were suggested by the Picot Taskforce. Its proposed ministerial advisory committee on education, independent of any government department, did not make it into the Tomorrow's Schools document (such overview independent standing advisory committees are rare in any government policy area). The Parent Advocacy Council and Community Education Forums did survive, but they were gone 
two years later. The latter never provided the real forum for looking at the supply of education across an area, or resolving local issues, or the channels for 'flax roots' issues to be discussed with the central government agencies, as intended by the Picot Taskforce (Mansell, 1993).

Thus the initial framing of Tomorrow's Schools set out some powerful aims, but, taking a New Public Management approach, gave no thought to how every school on its own could achieve its aims, in the absence of relationships beyond the school which might help develop the adult capability and capacity to really change learning opportunities and outcomes.

\section{The first two phases of self-managing schools 1989- 2009}

\section{Separation and distrust: the 1990s}

It is not possible here to describe all that occurred in the 1990s as schools found their feet - and identity - in the new environment. The section that follows aims to provide illustrations of some key dimensions of the first phase that continue to flavour the way the New Zealand system works, particularly those that inhibit adult learning and inquiry, and the kind of collective sense-making that is needed to tackle the complex challenges of education. In this section I draw particularly on NZCER's national surveys conducted in 1989, 1990, 1991, 1993, 1996, 1999, 2003, and $2007^{4}$, and studies of changes in the role of the principal (Wylie, 1997a) and the role of boards of trustees (Wylie 1997b).

\section{Forming identity}

Longitudinal studies of children's development show the importance of early opportunities to establish useful (or otherwise) habits (e.g., Wylie, Hipkins \& Hodgen, 2008). Such a focus on early opportunities and their role in establishing habits is a useful one when thinking about what New Zealand schools have become over the last twenty years.

One of the first tasks for schools in the new environment was to define themselves through their charter. This was to be the "contract" between the school and its community on the one hand, and its funder, 
the Ministry of Education, on the other. Many approached this by looking for things that made their school distinct. Arguably this emphasis on self-definition laid the ground for school leaders to later emphasise the uniqueness of their schools, sometimes as a reason to be left alone, and sometimes as a reason to disregard advice from government agencies that was well founded.

Self-definition also occurred as schools made spending decisions. Property refurbishment loomed large in many schools, partly because the reforms occurred in a period when there was a large backlog of "deferred maintenance", and partly because the look of a school became important. It is easy to tie this concern about the look of a school to the concern with attracting students, when operational funding and staff numbers were more tightly tied to student numbers than before, and parents were reminded of their ability to choose their child's school. But focusing on property also provided tangible evidence of the school's new decision-making powers, and its distinctiveness, its stand-alone identity.

The first community education forum to be held, which attempted to take a co-ordinated approach to the provision of schools in a Wellington area, ended with the schools that had wanted to take advantage of their separateness to extend the year levels they covered - at some cost to the rolls of other local schools - being allowed to do so. This was because the then Minister of Education gave more weight to school self-management than systemic effects (Mansell, 1993): It was an early lesson in the scope available to an entrepreneurial rather than a collegial approach among school leaders.

Similar lessons on the ways in which schools could define national guidelines for themselves came as schools reframed the objectives in the mandatory parts of the charter - to be used by ERO as the yardstick to assess their performance - as abstract statements rather than specific goals. It was common to describe existing practice, things that the school felt safe with, rather than to set challenging targets (Wylie, 1995a).

The charter framework did set equity issues and the Treaty of Waitangi before boards of trustees, parents who took part in consultation, and school staff. But there was little material from the Ministry of Education to inform school discussions of equity and the Treaty of Waitangi - nothing that might have challenged prevalent beliefs that equity was about access, not outcomes (Middleton \& 
Oliver, 1990). Although the implementation unit of the outgoing Department of Education, set up to support the transition, had staff who hoped that charters might contain clauses with teeth - that could change practice - they had no mechanisms or relationships to work with schools, to shift assumptions, and encourage the new adult learning that was needed to do things differently.

As the schools were tasked with new responsibilities, the Department of Education was also changing into the policy-focused Ministry of Education at the same time as the detail of implementation needed to be worked out and conveyed to schools (Butterfield, 1998). The initial year or two of Tomorrow's Schools was a period of great rush, uncertainty, and mixed messages that contributed to distrust of the government agencies and the sense that it was up to schools to make their own way.

Given the pace at which schools had to take on their new responsibilities, it is also not surprising that school leaders were cautious about setting challenging goals, and cautious about change in actual teaching practice. Nor, in most schools, were they being asked by boards or parents to make changes in practice. There are a number of reasons for this, particularly the high level of trust many parents had in teachers and schools before the reforms (Wylie, 1995b); and general parental caution about innovation in education (Lubienski, 2009; Wylie, 1998a). This parental caution continues to have ongoing implications for assumptions that more parental choice of school will foster innovation.

Principal work hours soared, with just under half in 1990 working more than 60 hours a week: a workload that has continued. Principals took on new administrative roles with minimal training and support (Wylie, 1997a). The hours New Zealand principals spent on administration remained the highest in international comparisons; and while many principals relished much about their decision-making powers, there has been a growing sense that this has come at the cost of their ability to focus on educational leadership (Robinson et al., 2009; Schagen \& Wylie, 2009). Principals and trustees also had to come to grips with the new role of the board of trustees. Much time was spent working on the policies each school was required to have and that ERO would be reviewing - not a bad thing in itself, where the policy area sparked investigation and collective thought, but the volume required within compressed timeframes meant that often this 
did not occur, and that "paperwork" headed the list of trustee and principal dissatisfactions with their work (and has remained a source of ongoing frustration).

\section{Supports and frameworks for individual schools}

After the initial flurry of professional development sessions funded by the government - most in groups, in seminar format - ongoing support for individual schools came largely in generic written form, with little customisation. The NZ School Trustees' Association (NZSTA) received some government funding to provide advice to individual schools as well as to produce handbooks and similar materials. The school advisory services, now located at the colleges of education, also provided guidance and some support. Locally, NZSTA, the teacher unions, and the principals' groups provided support and stepped in, usually informally. But one of the growing refrains from the sector organisations was that those who most needed help were least likely to seek it, or seek it too late. "Help" becomes an issue where there is no systematic ongoing support or understanding of the need for ongoing professional learning, or that institutions do not work at their best with their doors closed.

In the 1990s, the reason most schools interacted with the Ministry of Education was to improve their allocation of funding and staffing. Otherwise, there were no processes for ongoing communication, and no joint work. Educators were brought into the Ministry - contracted to work on the new curriculum documents, with core decisions already made, rather than working with Ministry of Education officials as partners in the original conceptual design.

By 1995, the Ministry of Education began to recognise that the variability of school self-management was producing uneven results, and it stepped beyond its original policy focus with the setting-up of the Schools Support project, originally intended to undertake one-off interventions rather than become part of the ongoing work of the Ministry of Education. By the late 1990s, this project had worked with up to 20 percent of New Zealand schools, sometimes at the local level, through informal work of sector groups, but increasingly through schooling improvement clusters. Originally, support for clusters was intended to be limited to three years, but in most cases it took this long to build relations between schools and partners, including the Ministry of Education and some innovative partnerships with iwi. A 2001 
evaluation of the Schools Support programme noted that such support was rarely a smooth process, and that building school capability was complex and took time. Schools in need of additional support also had common issues such as the inability to retain teachers, roll decline, lack of community resources and lack of "assessment literacy". All these issues had implications for "system-wide infrastructure or policies" (McCauley \& Roddick, 2001).

Three of the 16 schooling improvement clusters in this phase arose from area-focused critical ERO reports that aroused much anger, distrust and defensiveness (Thrupp \& Smith, 1999). In general, people in schools regarded ERO with wariness, expressing concerns about the variability of reviewers and criteria, the focus on documentation and policies that framed the reviews in terms of compliance rather than educational quality, and ERO's release of results before discussing them with the school (Wylie, 1997c). But schools did take notice of ERO reviews - they wanted to remain within the regular 3-yearly review cycle, rather than be deemed in need of supplementary review. Their changes to school practice and procedures as a result of reviews, however, tended to be more minor than major.

Interestingly, principals wanted more advice from ERO in relation to its analysis and recommendations (e.g., Wylie, 1999). This is one of the signs that many were keen for discussion, for insights, and for connections to other schools or programmes that could improve teaching and learning for their school's students. Yet competition between schools, or the sense that one had to present one's school in the best possible light in every situation outside the school, became more pronounced with school self-management, and seemed to inhibit educators initiating such connections, or sharing their successes. Most principals attended sector organisation meetings and conferences, but there was not much visiting of other schools, or the development of cross-school curriculum networks of teachers. Secondary subject association groups, which had provided such networks, lost some of their strength in the early days of school self-management, arguably as there was less connection with the Ministry of Education, and as school focus became more internal.

Nonetheless, this more inward focus did not seem to lead to more collective work within schools. One indicator of school effectiveness that was known in 1989 was whether teachers had some non-contact time to plan and work together (Mortimore, Sammons, Stoll, Lewis \& 
Ecob, 1988). Rather than this indicator improving over the first decade of self-managing schools, it stayed static in primary schools, and then declined (Wylie 1999). Perhaps the volume of change in this period played a part - but the lack of change here also shows that simply making schools self-managing did not systemically lead schools to act on known information, or ask themselves fundamental questions about the efficacy of their own practice that might lead to schools taking action themselves.

Tomorrow's Schools, and its focus on administration as a lever for educational change, had interrupted the development of a draft national curriculum framework, which was based on substantial community and educational discussion, and was to replace a collection of subject specific syllabi and guidelines that were developed gradually and individually. When work resumed, "curriculum policy shifted from a focus on content, experiences, and activities to curriculum policy based on outcomes" (Ministry of Education, 2002). The New Zealand Curriculum Framework was published in 1993 (Ministry of Education 1993), but not gazetted; the eight curriculum statements that followed in swift order for implementation from 1994 to 2003 were gazetted, with outcomes described in terms of broad achievement objectives. Schools were not left alone to make sense of the statements; some professional development relating to each curriculum statement was centrally funded, within a limited timeframe.

The NZCER national surveys showed a link between teachers' views that the Tomorrow's Schools reforms had improved children's learning, and their participation in curriculum professional development and use of the new statements (Wylie, 1997d, 1999). This link made some sense, particularly when the surveys also showed that teachers were experiencing some isolation, and where very few schools seemed to have developed a curriculum that was distinctive, which teachers would need to abandon to be consistent with the new national framework. Yet the cumulative volume of curriculum statements, and the achievement objectives within each of these statements, the need to switch to focus on a new curriculum area every year or two, and the focus of professional development provided on the interpretation of the new statements mitigated against developing depth, or the integration of the essential skills contained in the framework. Bolstad (2005) notes that the volume of change and the 
nature of the professional development may have made teachers less confident that they could use the scope of the framework to shape their school's actual curriculum.

The new curriculum statements were used by ERO reviewers as key criteria of their reviews. Primary teacher work hours jumped markedly between 1996 and 1999, particularly increasing the time spent on assessment. There were suggestions that teachers were probably over-assessing, with a mix of their own assessments using the achievement objectives, and standardised assessments. ERO in 1999 commented on the lack of nationally referenced curriculumlinked tools for assessing student progress and achievement, highlighting the difficulty of simultaneously developing new curricula and assessments to match (ERO, 1999). The NZCER national surveys showed that teachers were interested in having more assessment resources and guides for specific curriculum areas.

The late 1990s also saw the start of contestable funding pools to encourage innovation in teaching and learning. The funding pools increasingly funded voluntary clusters of schools to work together, particularly around ICT. Many schools took part primarily to gain additional resources for their own separate use, but some schools did develop habits of communication across schools, and even joint projects. However, schools were not given any guidance or facilitation to work together in the most effective manner. The only national use of clusters to provide ongoing support to schools was with the allocation of Resource Teachers of Learning and Behaviour in relation to students with moderate special needs. School principals managed these clusters. The variability in the allocation of this resource and its usefulness was evident in 2000 (Wylie, 2000a), and remained a concern in 2009 (ERO, 2009): an object lesson in the difficulty of sharing resources and getting national consistency when so much of the learning for schools since 1989 has been that their responsibility is to each school alone.

\section{Patterns at a system level}

From a bird's eye view, the New Zealand education system, by the end of the 1990s, seemed more uneven than it had been in 1989. So much of what happened at individual schools was indeed down to the capability and capacity of those who made a particular school: not just the educators, but the students, their parents, and the community 
around them. The system was more stratified: enrolments increased in the high socio-economic decile schools, ${ }^{5}$ and fell in the lowest socioeconomic decile schools, making it harder for those who served the most educationally needy students (Fiske \& Ladd, 2000; Harker, 2000a, 2000b; Lauder \& Hughes, 1999; Pearce \& Gordon, 2005; Thrupp, 2007a, 2007b; Wylie, 1998a, 2006). Low decile schools attracted good teachers - there is still a strong moral purpose among many New Zealand educators - but they also lost teachers to schools where the ask was less (or different) (Ritchie, 2004). Low decile schools were more subject to the vagaries of teacher supply, more likely to have to do more than their share of working with provisionally registered teachers, or immigrant teachers used to different educational approaches. Some schools continued to struggle to attract and then retain experienced principals, particularly small schools, those in rural areas, with high Māori enrolment, or that were low decile (Wylie, 1998b).

Per-student funding was insufficient on its own to support the development and expansion of kura kaupapa Māori, whose numbers were at one stage capped because of the increasingly evident lack of fluent teachers and resources, both of which needed national supportive mechanisms to create and increase. Per-student funding was also inadequate when it came to improving educational opportunities for students with special needs (Wylie 2000b).

There was some evidence that the increased stratification of schools depressed qualification levels in the lowest decile secondary schools (Fiske \& Ladd, 2000). Student performance on the international tests generally showed little change; and the New Zealand results for mathematics and science were termed 'mediocre' and 'disappointing' (Minister of Education, 1998). No progress had been made in reducing the number of low achievers, or closing the gaps between students related to differences in their home resources. The international test data prompted two important developments: the Mathematics and Science Taskforce in 1997, and the Literacy Taskforce in 1999. These taskforces were important because they marked a turn to collective projects to identify issues and propose new paths forward, which brought together educators, researchers, and Ministry officials. 


\section{Phase 2: Developing capability and capacity and shared ownership}

Thus, towards the end of the first phase of systemic school selfmanagement seeds were sown for more central initiation of support for schools. These supports also had a greater focus on teaching and learning, rather than administration. In primary and intermediate schools, this second phase had a more spacious feel about it than the first. Central initiatives used a developmental approach, coupled with ongoing evaluation or review, which allowed for any learning to be used in making changes to the supports or frameworks that schools would use. There was some tightening of the accountability framework around planning and reporting, but this framework also emphasised school self-review and analysis of progress, aiming to shift schools from thinking of accountability in terms of compliance (or in terms simply of assuming quality from student roll numbers) to thinking of accountability in strategic terms of ongoing development real self-management.

The two taskforces paved the way for a more coherent approach to professional development, based on existing knowledge or understanding of what was likely to improve professional capability in schools, but also building in ongoing evaluation and openness to using the results to change the approach: collective work rather than predecided. Mathematics practice has changed in many schools as a result of the Numeracy Initiative, with some achievement gains apparent (Ministry of Education 2009). Literacy practice nationally has seen more variable change and gains, since there was not a single project, and a smaller number of schools has been involved. Some of these projects have been centrally funded through professional development contracts (e.g., the Literacy Professional Development Project); others through partnerships of researchers and schools, funded through schooling improvement budgets, or the Teaching and Research Learning Initiative (TLRI), also funded by the Ministry of Education. Where gains in achievement are most marked and sustained, there has been a deliberate building of school capacity for evidence-based inquiry in literacy (Lai, McNaughton, Timperley \& Hsaio, 2009).

Schools began to use more evidence-based analysis of student performance because they had better access to sound, contemporary 
curriculum-linked assessments including national benchmarks. The Ministry funded the development and availability of a diverse number of assessment resources, including asTTle (Assessment Tools for Teaching and Learning) in mathematics, reading and writing, a set of assessment items for each curriculum level that teachers could use to create their own tests; the Assessment Resource Banks, in English, mathematics, and science; curriculum exemplars; and most recently, a set of literacy progressions. Work on the uses of assessment for learning, including the formative use of achievement and progress information, has been included in centrally funded professional development through the Assess to Learn (ATOL) programme, with some gains for achievement (Poskitt \& Taylor, 2008). Such professional development has, however, not been universally available.

A curriculum stocktake in 2002 went beyond a simple evaluation of "implementation" to look at the nature of the curriculum and its meaning, and paved the way for the development of a much more coherent and richer framework that asked for more collective work both within and across schools. There was meaningful involvement of educators along the way, in discussions and contributions to the development of the framework. Educators also worked with the draft curriculum to experiment with changes in teaching practice and ways of working in schools, particularly around the key competencies, and in sharing experiences between schools so that by the time of its introduction in 2009, the New Zealand Curriculum had become "owned" by most educators.

This more formative approach to the New Zealand Curriculum contrasts favourably with the rapid introduction of NCEA in the early and middle stretches of this second phase, although there had been moves away from the norm-referenced approach to secondary qualifications, with sector support. But the actual introduction of the new secondary qualifications followed more the compressed model of curriculum introduction of the first phase, at the cost of initial sector ownership of the new qualifications, and then of vulnerability of the qualifications to criticism (Alison, 2005; Brooking, 2006; PPTA, 2005).

Māori student engagement and performance moved to the forefront in this phase, as Māori made it more pressing, through the Hui Taumata Matauranga in the early 2000s and the development of the 
analyses that led to the Te Kotahitanga professional development (Bishop, Berryman, Cavanagh \& Teddy, 2007) funded by the Ministry of Education. This professional development has had a powerful impression on practice in some secondary schools, and has contributed to the growth of much greater attention in New Zealand to the role of teaching practice in encouraging active student engagement in their learning.

This second phase was a particularly fertile one for the contribution of educational researchers to teaching practice, particularly where they worked alongside teachers in iterative inquirybased models that supported cultures of inquiry rather than mechanical emulation, and where they synthesised research findings on the relationship of educational practices and student outcomes, such as in the Best Evidence Syntheses ${ }^{6}$ and Hattie's (2009) metaanalysis work. Much of this work aimed at building the capacity that embeds a desire for ongoing action, and learning from that action, at school level. Central support from the Ministry of Education, and understanding among key players within the Ministry, that schools needed evidence-based but not prescriptive support played the critical foundational role in much of this work.

This phase also saw the spread of school clusters, more focused than before on collaborative work, rather than using the cluster (just) as a means to gain additional funds for each school to use separately. The clusters that seemed to move fastest in terms of working on joint inquiries were those that had already developed trust and processes through earlier contracts to work together.

The new professional development, work on the new curriculum, and the Extending High Standards for All Students (EHSAS) and ICT clusters allowed some new networks to form and grow, with teachers and principals sharing knowledge, starting to visit each other's schools, and becoming more interested in evidence of learning and how that related to changes in teaching practice and school organisation.

\section{Continuing tensions}

Nonetheless, at the end of 2009, alongside all these promising new approaches - with inquiry, good tools, and collaborative approaches the original principle of separation between individual schools, and 
between schools and the government agencies, remained intact. Schools continued to be conscious of competing with each other for students, particularly in urban areas. The annual school reports arising from the changes to the planning and reporting framework had not occasioned deeper communication between the Ministry of Education and schools, or ways to provide support so that schools can avoid getting into difficulties (Wylie, forthcoming). The NZCER surveys showed an increasing desire on the part of principals - and boards - to have more advice and support, and to have meaningful discussions focused on the school's goals, progress, and issues. Principals welcomed changes to ERO reviews that made them less compliancefocused, with recommendations usually related to teaching and learning, but some still would welcome more advice (Schagen \& Wylie, 2009). Trustees showed more interest in having Ministry of Education support around the appointment of principals and their appraisal (Wylie, 2007a). The Audit Office criticised the lack of Ministry of Education support for boards of trustees (Office of the Auditor-General, 2008). There were signs of interest from many schools in having working relationships with government agencies, but on the other 'side', signs of uncertainty and caution from the government agencies, and uncertainty about how to support selfmanaging schools in ways that did not tamper with the central principle of school self-management (Wylie, 2009).

Thus while the emphasis on developing capability and joint work showed gains, it also exposed the weakness of the underlying structure, which treats school self-management as something which cannot easily allow ongoing relationships of formative and useful accountability, or challenge/support. This became apparent at the 2009 Cognition Institute seminar looking back on the last 20 years (Langley, 2009). Among the diverse contributors (policymakers, practitioners, researchers) to the seminar, there was sometimes a surprising commonality of conclusion that the New Zealand structures and processes were being outstripped by the real challenges in improving learning, particularly for those for whom the reforms were originally intended.

The New Zealand educational structures and processes are also, at a system level, being outstripped by what is known now about the nature of learning that was not known 20 years ago - for adults as well as children and adolescents - and the essential contribution of 
collective learning and action (e.g., professional learning communities, distributed leadership) and the continuous attention that must go to developing and supporting capability and capacity.

I see two alternative frames ahead. The first frame continues to treat self-managing schools as separate entities. However, as policymakers become impatient to see faster shifts in performance, there will be increasingly tighter parameters of accountability of a summative kind. This may produce some shifts among individual schools on what is used as the measure of performance, but cannot address the systemic issues that contribute to the quality of teaching and learning. There are other risks too, particularly around the further development of the New Zealand Curriculum, since summative accountability systems find it extremely difficult, and too costly, to measure performance in a comprehensive way, across the full curriculum. And by continuing to hold schools and government education agencies at arm's length from each other, the solipsism of the first phase of Tomorrow's Schools becomes only further entrenched, with each "side" - schools on one side, the government agencies on the other - becoming increasingly defensive.

The second frame is to position self-managing schools within school districts. This could maintain the undoubted strengths that a focus on individual school culture and decision-making can have if it is anchored within a supportive collective, and sustained by the ability to recruit and retain good teachers - a systemic issue as well as an individual school responsibility. The school districts should not be run as bureaucracies, which would not work in New Zealand, but as networks anchored by the Ministry of Education. Such an approach would enable schools to work together and share resources, with principals who take joint responsibility to work together on thorny local issues, including equitable enrolment schemes that do not exacerbate social segregation. It would also require principals to have clear lines of accountability that are primarily formative, or developmental - but with repercussions for non-performance. The Edmonton school district in Alberta, Canada provides a good example of what is possible (Wylie, 2007b). This path uses what we now know about the value of collective learning and action in a context that matters to those involved.

As I write in 2010, it is the first frame that is starting to be drawn, but with some lines pulling through from the second phase of the 
Tomorrow's Schools reforms, including the undoubted strengthening of professional practice that has occurred in many schools. Yet that very strengthening feeds tensions and disappointments with the next framing of school self-management. Confident schools may create their own networks: But a strong education system needs everyone connected, respected, and learning. As a country, we have yet to find ways to achieve this within the overarching self-managing schools model, and until we do, the aims of the Tomorrow's School policy will remain elusive.

\section{References}

Alison, J. (2005). Teachers talk about NCEA. (Research report on focus groups with secondary teachers). Wellington: Post Primary Teachers' Association.

Beeby, C. E. (1983). Centennial address. National Education, 65(3), 106-110.

Bishop, R., Berryman, M., Cavanagh, T., \& Teddy, L. (2007). Te Kotahitanga phase 2. Wellington: Ministry of Education.

Bolstad, R. (2005). School-based curriculum development: Is it coming back into fashion? Curriculum Matters, 1, 187-209.

Brooking, K. (2006, December). The NCEA: Competing viewpoints since implementation and the debate about its future. Presentation at NZARE Conference, Rotorua.

Butterfield, G. S. (1998). Reforming education: The New Zealand experience. Wellington: Ministry of Education.

Codd, J. A. (1990). Managerialism: The problem with today's schools. Delta, $44,17-25$.

Dale, R., \& Jesson, J. (1993). Mainstreaming education: The role of the State Services Commission. New Zealand Annual Review of Education 2, 7-34.

Education Review Office. (1999). Student assessment: Practices in primary schools. Wellington: Author.

Education Review Office. (2009). Resource teachers: learning and behaviour: An evaluation of cluster management. Wellington: Author.

Elmore, R. (2004). School reform from the inside out: Policy, practice and performance. Cambridge, MA: Harvard University Press.

Eppel, E. (2009). Curriculum, teaching and learning: A celebratory review of a very complex and evolving landscape. In J. Langley (Ed.), Tomorrow's schools 20 years on... Auckland: Cognition Institute.

Fiske, E. B., \& Ladd, H. F. (2000). When schools compete: A cautionary tale. Washington, DC: Brookings Institution Press. 
Gregory, R. (2003). All the king's horses and all the king's men: Putting New Zealand's public sector back together again. International Public Management Review, 4(2), 41-58.

Harker, R. (2000a). Roll change and the removal of zoning, 1991-1998. SET: Research Information for Teachers 2, 4-6.

Harker, R. (2000b, December). The impact of de-zoning on New Zealand secondary schools. Paper given at NZARE Annual Conference, University of Waikato, Hamilton.

Hattie, J. (2009). Visible learning: A synthesis of over 800 meta-analyses relating to achievement. Oxford: Routledge.

Lai, M. K., McNaughton, S., Timperley, H., \& Hsaio, S. (2009). Sustained continued acceleration in reading comprehension achievement following an intervention. Educational Assessment, Evaluation and Accountability, 21(1), $81-100$.

Langley, J. (Ed). (2009). Tomorrow's schools 20 years on ... Auckland: Cognition Institute.

Lauder, H., \& Hughes, D. (1999). Trading in futures: Why markets in education don't work. Buckingham: Open University Press.

Lauder, H., Wylie, C., \& Parker-Taunoa, R. (1990). Citizens or consumers? The politics of educational reform: An introduction. In H. Lauder \& C. Wylie (Eds.), Towards successful schooling (pp. 1-14). Basingstoke: Falmer Press.

Lough, N. (1990). Today's schools: A review of the education reform implementation process. Wellington: Ministry of Education.

Lubienski, C. (2009). Do quasi-markets foster innovation in education? A comparative perspective (OECD Education Working Paper No. 25). Paris: OECD.

Mansell, R. L. (1993). Community forum on education in Wellington's eastern suburbs: A case study on choice and democratic community participation in New Zealand education policy. Unpublished Master's thesis, Victoria University of Wellington.

McCauley, L., \& Roddick, S. (2001). An evaluation of schools support. Wellington: Ministry of Education.

Middleton, S., \& Oliver, D. (1990). Who governs our schools? Hamilton: Monitoring Today's Schools Research Project, University of Waikato.

Minister of Education. (1988). Tomorrow's schools: The reform of education administration in New Zealand. Wellington: Government Printer.

Minister of Education. (1998). New Zealand schools 97. Wellington: Ministry of Education. 
Minister of Education. (2010). New Zealand schools 09. Wellington: Ministry of Education.

Ministry of Education. (1993). The New Zealand curriculum framework. Wellington: Learning. Media.

Ministry of Education. (2002). Curriculum stocktake report. Wellington: Author.

Ministry of Education. (2007). The New Zealand curriculum. Wellington: Author.

Ministry of Education. (2009). Findings from the New Zealand Numeracy Development Projects 2008. Wellington: Author.

Mortimore, P., Sammons, P., Stoll, L., Lewis, D., \& Ecob, R. (1988). School matters: The junior years. Wells, Somerset: Open Books.

Norman, R., \& Gregory, R. (2003). Paradoxes and pendulum swings: Performance management in New Zealand's public sector. Australian Journal of Public Administration, 62(4), 35-49.

Office of the Auditor-General. (2008). Ministry of Education: Monitoring and supporting boards of trustees. Wellington: Author.

Openshaw, R. (2009). Reforming New Zealand secondary education: The Picot report and the road to radical reform. New York: Palgrave Macmillan.

Pearce, D., \& Gordon, L. (2005). In the zone: New Zealand's legislation for a system of school choice and its effects. London Review of Education, 3(2), 145-157.

Poskitt, J., \& Taylor, K. (2008). National education findings of Assess to Learn (AtoL) report. Retrieved from http://www.educationcounts.govt.nz/ data/assets/pdf_file/0004/28165/Eval_Nat_Edu_Findings_Formatted2.pdf

PPTA. (2005). The NCEA: A work in progress. Paper presented at the PPTA Annual Conference.

Ramsay, P. D. K. (1993). Picot: Vision and reality in New Zealand schools: An insider's view. In B. Lingard, J. Knight \& P. Porter (Eds.), Schooling reform in hard times (pp. 261-283). London: Falmer Press.

Ritchie, G. (2004). Quantifying the effects of teacher movements between schools in New Zealand: To schools that hath shall be given. Journal of Education Policy, 19(1), 57-79.

Robinson, V., Hohepa, M., \& Lloyd, C. (2009). School leadership and student outcomes: Identifying what works and why: Best evidence synthesis iteration [BES]. Wellington: Ministry of Education.

Schagen, S., \& Wylie, C. (2009). School resources, culture and connections. Wellington: NZCER. 
Schick, A. (2001). Reflections on the New Zealand model. Retrieved from http://www.treasury.govt.nz/publications/mediaspeeches/guestlectures/schick-aug01/schick-rnzm01.pdf

State Services Commission. (1999). Improving accountability: Setting the scene (Occasional article No. 10). Wellington: Author.

Thrupp, M. (2007a). Education's inconvenient truth: Part one - persistent middle class advantage. New Zealand Journal of Teachers' Work, 4(2), 77-88.

Thrupp, M. (2007b). Education's 'inconvenient truth': Part two - the middle classes have too many friends in education. New Zealand Journal of Teachers' Work, 5(1), 54-62.

Thrupp, M., \& Smith, R. (1999). A decade of ERO. New Zealand Journal of Educational Studies, 31(1), 186-198.

Treasury. (2009). Challenges and choices: New Zealand's long-term fiscal statement. Wellington: Author.

Waitangi Tribunal. (2010). Te Reo Māori: Pre-publication report 262. Retrieved from http://www.waitangitribunal.govt.nz/scripts/reports/reports/262/056831 F7-3388-45B5-B553-A37B8084D018.pdf

Wylie, C. (1988). Education in Report of the Royal Commission on Social Policy Vol IV (pp 117-148). Wellington: Royal Commission on Social Policy.

Wylie, C. (1995a). Contrary currents: The application of the public sector reform framework in education. New Zealand Journal of Educational Studies, 30(2), 149-164.

Wylie, C. (1995b). The shift to school-based management in New Zealand: The school view. In D. Carter \& M. O'Neill (Eds.), Case studies in educational change: An international perspective (pp. 61-80). London: Falmer Press.

Wylie, C. (1997a). At the centre of the web: The role of the New Zealand primary school principal within a decentralized education system. Wellington: New Zealand Council for Educational Research.

Wylie, C. (1997b). The role of New Zealand school boards in 1997. Wellington: NZ School Trustees' Association.

Wylie, C. (1997c). Primary principals' experiences of ERO reviews. Wellington: New Zealand Principals' Federation.

Wylie, C. (1997d). Self-managing schools seven years on: What have we learnt? Wellington, New Zealand: Council for Educational Research.

Wylie, C. (1998a). Can vouchers deliver better education? A review of the literature, with special reference to New Zealand. Wellington: New Zealand Council for Educational Research.

Wylie, C. (1998b). Principal appointments 1997. Report for NZ Principals' Federation. 
Wylie, C. (1999). Ten years on: How schools view educational reform. Wellington: New Zealand Council for Educational Research.

Wylie, C. (2000a). New Zealand: Innovation and tensions in a devolved education system. In T. Townsend \& Yin Cheong Cheng (Ed.), Educational change and development in the Asia-Pacific region: Challenges for the future (pp. 267-284). Lisse, Netherlands: Swets \& Zeitlinger.

Wylie, C. (2000b). Picking up the pieces: Review of Special Education 2000. Wellington: Ministry of Education.

Wylie, C. (2006). What is the reality of school competition? Retrieved from http://www.ncspe.org/publications_files/OP126.pdf

Wylie, C. (2007a). School governance in New Zealand: How is it working? Wellington: New Zealand Council for Educational Research.

Wylie, C. (2007b). What can New Zealand learn from Edmonton? Wellington: New Zealand Council for Educational Research.

Wylie, C. (2009). Getting more from school self-management. In J. Langley (Ed.), Tomorrow's schools 20 years on ... Auckland: Cognition Institute.

Wylie, C. (forthcoming). New Zealand: Challenges around capability improvements in a system of charter schools.

Wylie, C., Hipkins, R., \& Hodgen, E. (2008). On the edge of adulthood: Young people's school and out-of-school experiences at 16. Wellington: Ministry of Education.

\section{The author}

Cathy Wylie is a Chief Researcher at the New Zealand Council for Educational Research. She has published and presented extensively on New Zealand educational policy and its impacts, particularly the country's experience with school self-management since 1989. Studies she has undertaken cover changes in school roles, relations between central government and schools, school accountability, school financial decisionmaking, and school improvement and development. She has led NZCER's programme of national surveys of schools since 1989. She also leads the longitudinal Competent Learners study of the roles of education, home, and leisure interests and friendships in educational engagement and performance, and in the development of learning identities, which has followed some 500 participants from early childhood education to age 20. Email: cathy.wylie@,nzcer.org.nz

1 Interestingly, some 30 percent of charter schools in the United States are now operated as part of networks run by organizations (both non-profit and for-profit), rather than operating entirely on their own. http://www.centerforpubliceducation.org/site/apps/nlnet/content3.aspx?c=lvIXIiN0JwE\&bl= $5868097 \& \mathrm{ct}=8089273 \&$ notoc $=1$

2 This article is a version of the Herbison lecture given at the NZARE conference at the end of 2009. The intention of the Herbison lecture is to provide an opportunity for experienced researchers to reflect on an area of their work. In the space of this article I cannot do justice to all the analysis and 
research which has been done on the genesis of the Tomorrow's Schools policy, and its impacts, and this is not intended as a full review of that work. Analysis of the origins of the reforms, the contested nature of mechanisms and processes, and initial changes can be found in the New Zealand Annual Review of Education 1992 and the New Zealand Journal of Educational Studies 31 (1) 1999; in Olssen, M. \& Morris Matthews, K. (Eds.) (1997) Education Policy in New Zealand: the 1990s and beyond. Palmerston North: Dunmore Press; and Codd, J., \& Sullivan, K. (2005), Educational Policy Directions in Aotearoa New Zealand. Melbourne: Thomson/Dunmore Press; and in the Dale \& Jesson article and the Lauder \& Wylie edited volume given in the references.

My thanks to the two anonymous reviewers for their comments, and to Robyn Baker for her encouragement and review.

3 The Tomorrow's Schools reforms with their mixed aims and processes, and then the New Public Management Lough review occurred under a Labour government. The National party was in power from late 1990 to late 1999, a decade that saw a continuation of the New Public Management approach, with some additional strands starting to address capability towards the end of their term. Labour and Labour-led governments held power from late 1999 to late 2008, a time that saw some tempering of the New Public Management approach (particularly in relation to full bulk funding of schools, including teacher salaries), and a sustained focus on capability building. A National-led government took power in late 2008, and the initial signs are of a renewed emphasis on New Public Management approaches, this time through the introduction of National Standards in primary schools, but also with some approaches to capability building that use both market and system-linkages with schools.

4 Reports of each survey can be found on www.nzcer.org.nz

5 New Zealand schools are allocated a decile ranking in relation to a set of indicators of socioeconomic disadvantage, based on census data related to parental addresses. This decile ranking is used to allocate around 15 percent of the total money spent on school operational funding, with the highest amounts going to decile 1schools. This acknowledgement of the additional demand on schools serving students in poorer areas stems from the equity aims of the Tomorrow's Schools reforms, but pressure from other schools meant that the original intention to limit this additional funding to just the schools in poor areas was extended to include schools up to decile 9.

6 The eight BES programme reports and other relevant summaries and articles are available at www.educationcounts.govt.nz/goto/BES. 